\title{
Evaluation of the essential amino acids and fatty acids of Citrullus lanatus and Annona muricata seeds
}

\author{
Adegoke, Bosede M. ${ }^{\mathrm{a}}$, Shittu, Suraj A. ${ }^{\mathrm{b}}$, Afolabi, Fatai ${ }^{\mathrm{c}}$, Oyekanmi, Adeyinka \\ M. ${ }^{\mathrm{d}}$, and Oyetola, Emmanuel O. ${ }^{\mathrm{e}}$ \\ a abosedeadegoke@yahoo.com \\ ${ }^{a, b, c, d}$ Department of Applied Sciences, Osun State Polytechnic, Iree, Nigeria. \\ ${ }^{e}$ Department of Chemical Sciences, Ajayi Crowdwer University, Oyo, Nigeria
}

\begin{abstract}
Looking into the prevalence of high level of macro and micronutrients malnutrition especially amongst the vulnerable sections in the country even at this time of dwindling economy and increasing prevalence of chronic degenerative diseases globally, the need for exploration of underutilized food parts is significant to overcome the nutritional disorders. Many seeds which we considered as waste and simply discard after taking the juicy part of the fruit may however be reservoir of many nutrients. The seeds of Citrullus lanatus (Watermelon) and Annona muricata (Soursop) were collected, dried and dehulled. They were thereafter pulverized and subjected to analysis to assess their nutritional qualities by identifying their essential amino acids and fatty acids. Results of the proximate analysis revealed that the seeds are rich sources of protein and fat. They also contain all the essential amino acids with leucine being predominant in watermelon and lysine in soursop. The seeds also contain essential fatty acids such as linoleic acids and linolenic acids. Overall, the results indicated that the seeds of watermelon and soursop are of high nutritional qualities as identified by the essential nutrients, hence, could be harnessed and incorporated in the diets (man and animal nutrition) to combat malnutrition.
\end{abstract}

Keywords: Amino acids, Annona muricata, Citrullus lanatus, fatty acids, malnutrition, nutrients

\section{Introduction}

Malnutrition sets in when the body is deprived of required nutrient; it is thus a major public health problem. There is however, the need for long term sustainable intervention that would reduce the deficiency. Food based approach; especially dietary diversification could increase consumption of nutrient rich food. This would however be valuable in combating debilitating health problems.

However, lack of knowledge of available foods, their usage, nutritional and health benefits pose problems especially with essential nutrient deficiencies. The knowledge of the nutrient composition of these foods will enhance their use and increase their utilization which will in turn help to improve the nutrient requirements of the populace.

In other to have a healthy population that can enhance development, the relationship between food, nutrition and health should be strengthened. In developing countries like ours, one of the ways of achieving this is through the exploitation of available but underutilized food resources, in other to satisfy the needs of the teeming population especially in a dwindling economy. 
There are different varieties of wild fruits that are in abundance in Nigeria but some of their fruit parts are underutilized, wherein the seeds that could be of health benefits especially in supplying the body with essential nutrients are discard.

One of these underutilized fruits is the Annona muricata (soursop) with its recent resurgence of interest in the fruit and basically considered to be a functional product mostly because of its pulp which is reported to contain numerous sources of vitamins and minerals (Onyechi et al., 2012).

In addition, Citrullus lanatus (watermelon), is one of the advocated fruits through which are numerous nutritional benefits to be derived. Unfortunately, when one think of the health benefits of these fruits, the seeds probably do not come to the mind, rather the sweet and juicy pulp while the seeds are normally disposed as waste.

Previous studies showed that seeds in general, contain higher concentration of protein and fats which are essential nutrients (Fasakin et al., 2008). However, information is scanty on the quality of the protein and fat. It is therefore possible to utilize the seeds as potential sources of nutrients to provide valuable added food product for human/animal consumption and thus play a significant role in the prevention or risk of diseases.

Soursop belongs to the family Annonaceae. It is locally called chap-chap in Yoruba and shawshopu in Igbo. Soursop is irregular in shape but most frequently the fruits are ovoid or heart shaped. The skin is thick, leathery and dark green with many short curved fleshy spines. The mesocarp contains numerous shiny dark brown flat seeds which is ovoid in shapes and mostly discarded after taking the juicy part. It is commonly found in southern and western part of Nigeria (Fasakin et al., 2008).

Watermelon belongs to the family Cucurbitaceae. It is found in grassland, mostly on sandy soil. It flourishes in dry climates and requires limited rainfall. It is cultivated in all tropical and subtropical countries as well as in temperate countries.

This study is therefore aimed at evaluating the quality of the seeds of watermelon and soursop by evaluating and identifying their essential amino acids and fatty acids which are index of nutrient qualities.

\section{Materials and Methods}

\subsection{Collection and Processing of Samples}

Annona muricata (Soursop) and Citrullus lanatus (Watermelon) fruits were collected from an orchard at Iree, Osun State, Nigeria. The seeds of both fruits were removed, washed and air-dried at room temperature $\left(28 \pm 2.00{ }^{\circ} \mathrm{C}\right)$ for two weeks. The seed coat of the seeds were removed by manual cracking and thereafter the dehulled seeds were pulverized using an electric blender (Holt Star, Model BE 768-2, John Holt Co., UK). The finely powdered samples were separately stored at room temperature in air- tight polythene bag until needed for analyses.

\subsection{Proximate composition determination (\%)}

The recommended methods of the Association of Official Analytical Chemist (AOAC, 2005) were employed in the determination of moisture, ash, crude protein, crude fibre and crude fat contents while carbohydrates content was determined by difference.

\subsection{Essential amino acid determination}

The analysis was performed on a Biochrom 30 amino acid analyzer by ion-exchange chromatography with post column derivatization using ninhydrin and monitored at $570 \mathrm{~nm}$. 


\subsection{Fatty acid determination}

This was done by employing the method as described by Igwe et al., (2011). $5 \mathrm{~g}$ of ground sample was extracted for $8 \mathrm{~h}$ with $1 \mathrm{~N}$ hexane for its oil. The extracted oil was saponified for $1 \mathrm{~h}$ with $15 \mathrm{ml}$ of $\mathrm{KOH}$ in methanol at $90^{\circ} \mathrm{C}$ and thereafter treated with $2 \mathrm{ml}$ of $1.4 \mathrm{~N} \mathrm{HCl}$ for $1 \mathrm{~h}$ and allowed to cool to room temperature. $15 \mathrm{ml}$ of $\mathrm{N}$ - heptane and $200 \mathrm{ml}$ of brine were thereafter added and mixed. $5 \mu \mathrm{l}$ of fatty acids methyl esters (FAMEs) solution was analysed using gas chromatography system for the fatty acids. The (FAMEs) extract was alongside analysed with standards.

\subsection{Statistical analysis}

The data obtained were subjected to T-test using statistical tool (SPSS 21) to analyse the data.

\section{Results}

Table 1: Percentage proximate composition of Annona muricata and Citrullus lanatus seed

\begin{tabular}{ccc}
\hline Parameters (\%) & Annona muricata & Citrullus lanatus \\
\hline Moisture Content & $5.27 \pm 0.09$ & $4.63 \pm 0.03$ \\
Protein & $26.53 \pm 0.17$ & $23.19 \pm 0.13$ \\
Ether Extract & $32.27 \pm 0.21$ & $29.46 \pm 0.12$ \\
Ash & $3.73 \pm 0.03$ & $5.55 \pm 0.01$ \\
Crude Fibre & $2.07 \pm 0.03$ & $2.63 \pm 0.01$ \\
Carbohydrates & $30.13 \pm 1.19$ & $34.54 \pm 2.11$ \\
\hline
\end{tabular}

Each value is a mean of three determinations $\pm \mathrm{SD}$.

Table 2: Essential amino acids composition of Annona muricata and Citrullus lanatus seed

\begin{tabular}{lcc}
\hline Parameters $(\%)$ & Annona muricata & Citrullus lanatus \\
\hline Histidine & $1.60 \pm 0.02$ & $1.59 \pm 0.01$ \\
Isoleucine & $2.16 \pm 0.09$ & $3.81 \pm 0.10$ \\
Leucine & $3.27 \pm 0.02$ & $5.65 \pm 0.13$ \\
Lysine & $5.06 \pm 0.17$ & $4.16 \pm 0.11$ \\
Methionine & $3.49 \pm 0.13$ & $1.89 \pm 0.02$ \\
Phenylalanine & $4.12 \pm 0.12$ & $4.12 \pm 0.19$ \\
Threonine & $0.12 \pm 0.01$ & $3.36 \pm 0.11$ \\
Valine & $2.14 \pm 0.07$ & $0.39 \pm 0.00$ \\
\end{tabular}

Each value is a mean of three determinations \pm SD.

Table 3: Fatty acids composition of Annona muricata and Citrullus lanatus seed

\begin{tabular}{lcc}
\hline Parameters $(\%)$ & Annona muricata & Citrullus lanatus \\
\hline Oleic acid & $55.36 \pm 6.12$ & $45.36 \pm 4.17$ \\
Linoleic acid & $0.53 \pm 0.11$ & $9.66 \pm 2.01$ \\
Linolenic acid & $9.66 \pm 1.14$ & $18.23 \pm 1.22$ \\
Arachidonic acid & $0.25 \pm 0.03$ & $1.49 \pm 0.08$ \\
\end{tabular}

Each value is a mean of three determinations \pm SD. 


\section{Discussion}

Essential nutrients are those nutrients that cannot be manufactured or synthesized in adequate amount by the body and must be provided through diets for normal physiological functions of the body (Young, 1994). This is an indication that the body is not self- sustaining, thus these nutrients are required to keep it functioning. Table 1 shows the result of the percentage proximate composition of the nutrients of soursop and watermelon seed. The most pertinent information is their crude protein of $26.53 \%$ and $23.19 \%$ respectively and the crude fat of $32.27 \%$ and $29.46 \%$ respectively. These are however, significantly $(\mathrm{p}<0.05)$ different. The crude protein content of both seeds were quantitatively higher than $24 \%$ reported for $P$. africana, also a lesser known seeds employed in a study of the biochemical assessment of $P$. africana seeds as a protein component of poultry feed (Oloyede and Abiola, 2004). Ojiako and Igwe (2007) also reported $C$. rutidosperma, L. siceraria and C. maxima seeds with protein contents of $11.73 \%, 8.93 \%$ and $16.80 \%$ respectively. Crude protein content of watermelon seed was however close to those reported for $S$. Indican $(24.74 \%)$ by Ojiako et al., (2010) and that of soursop quantitatively close to of fluted pumpkin seed $(28.7 \%)$ as reported by Fagbemi and Oshodi (1991). The fat content of soursop and watermelon seeds respectively were higher when compared to those reported for $C$. rutidosperma (7.20\%) Ojiako and Igwe (2007). These are indications that both seeds are rich sources of protein and fat amongst others. However, the ether extract of both seeds are slightly lower than those reported by Omosuli et al. (2009) for soybean (34. 95\%).

Proteins are made up of amino acids which are the building blocks of life. The human body can manufacture all but nine of the 20 basic amino acids. These nine amino acids are termed essential amino acids which must be must be derived from what we eat. The inability of humans/animals to manufacture certain amino acid calls for the need to cater for the body's inadequacies by sourcing for the essential amino acids in plants, particularly those that are overlooked but of tremendous source. One of the qualities of protein is therefore adjudged by the amount of essential amino acids it contains. Interestingly, the seeds of soursop and watermelon contain virtually all these essential amino acids except one which is not accounted for (Tryptophan) due to the complexity in its determination because it is easily destroyed upon hydrolysis. The results of the essential amino acid profile of soursop and watermelon seeds (Table 2) indicate that the seeds are rich in virtually all the essential amino acids. Of all the essential amino acids present in soursop seed, Lysine, which has been reported to be the limiting amino acid in most cereal grains (Young and Pellett, 1994) ranks the most predominant which is also significantly $(\mathrm{p}<0.05)$ higher than that obtained in watermelon seed where the concentration of Leucine is significantly $(\mathrm{p}<0.05)$ increased compared to soursop seed. Soursop seeds can thus, conveniently be used in the supplementation of animal feeds for their optimal growth.

Furthermore, not only is the amount of essential amino acids indicative of good nutritional value, so also are the presence of essential fatty acids. The seeds of soursop and watermelon revealed to contain the two essential fatty acids (Linoleic acid and Linolenic acid) which is one of the indicator of good qualities of fats (Whitney and Rolfes, 2008), though significantly ( $\mathrm{p}<0.05)$ higher in watermelon seed than in soursop seed. Low levels of essential fatty acids have been linked to osteoporosis (Kruger and Horrobin, 1997). Essential fatty acids are required for growth and development, proper brain functioning (Uauy et al., 2001), skin health and metabolism (Callaway et al., 2005). Linoleic acid had earlier been reported to prevent skin diseases, fight cancer cells and used in the treatment of arthritis (Reiltel and McDonald, 2006). The fatty acid could also prevent blood clot and improve the functioning of the immune system (Cunnane, 2003). Of all the fatty acids assessed, Oleic acid has the highest composition in both seeds. However, it was significantly $(\mathrm{p}<0.05)$ higher in soursop seed than in watermelon seed (Table 3). Oleic acid, a monounsaturated fatty acid, had been linked to have the ability to reduce blood pressure (Ruiz-Guitierrez et al., 1996) and protect cells from free radical damage (Haug et al., 2007). It had also been reported to prevent type 2 diabetes (Vassilious et al., 2009) and prevent ulcerative colitis (de Silva et al., 2014). Also contained in both seed samples is Arachidonic acid, a polyunsaturated fatty acid which the body requires to function properly. It was reported to be manufactured in the body when adequate amount of linoleic acid is consumed, making it non-essential fatty acid. It however, 
becomes essential if there is a deficiency in linoleic acid to be converted to arachidonic acid, thus, making it a conditional or semi-essential essential fatty acid (Rivers et al., 1975).

\section{Conclusion}

Soursop and watermelon seeds appear to be quite promising to prevent malnutrition and may be harnessed and incorporated in the diets (man and animal nutrition) to maintain health and combat malnutrition as a result of their nutritional qualities as identified by the essential nutrients.

\section{References}

Onyechi, A. U., Ibeanu, V. N., Eme, P. E., Kelechi, M., 2012. Nutrient, Phytochemical Composition and Sensory Evaluation of Soursop (Annona muricata) Pulp and Drink in South Eastern Nigeria. Int. J. Basic and Applied Sci. 12(6), p. 53-57.

Fasakin, A.O. Fehintola, E. O., Obijole, O. A., Oseni, O. A., 2008. Compositional Analyses of the Seed of Soursop, Annona muricata as a Potential Animal Feed Supplement. Scientific Research Essay 3(10), p. 521-523.

A.O.A.C., 2005. Association of Official Analytical Chemists Offical methods of analysis. (18th ed). Maryland, USA.

Igwe, C. U. Nwaogu, L. A. and Okwu, G. N., 2011. Chemical Analysis of an Edible African Termite, Maerotermes nigeriensis: A Potential Antidote to Food Security Problem. Biochem and Anal. Biochem. 1, 105.

Young, V. R., 1994. Adult Amino Acid Requirements: The Case of a Major Revision in Clinical Recommendations. Journal of Nutrition. Vol. 124, (8 Suppl), p. 1517s-1523s).

Oloyede, O. B. and Abiola, B. M., 2004. Biochemical Assessment of Processed Prosopis africana as the Protein Component of Poultry Feed. Nigerian Journal of Pure and Appl. Sci. 19, p. 1627-1633.

Ojiako, O. A. and Igwe, C. U., 2007. Nutritional and Antioxident Composition of C.rutidosperma, L. Siceraria and C. Maxima Seeds from Nigeria. Journal of Medicinal Food 10(4), p. 735-738.

Ojiako, O. A. and Igwe, C. U., Agha, N. C., Ogbuji, C. A., Onwuliri, V. A., 2010. Protein and Amino acid Compositions of Sphenostylis slenocerpa, Sesanum indicum. Monodora myristica and Afzelia africana Seeds from Nigeria. Pakistan Jour. of Nutr. 9, p. 368-272.

Fagbemi, T. N. and Oshodi, A., 1991. Chemical composition and functional properties of full-fat fluted pumpkin seed flour, Nig. Food J. 9, p. 26-32.

Omosuli, V. S., Ibrahim, A. T. Oloye, D., Agbaje, R. and Jude-Ojei, B., 2009. Proximate and Mineral Composition of Roasted and Defatted Cashew Nut Flour. Parkistan Journ. of Nutrition 8, p. 16491651 .

Young, V. R. and Pellett , P. L., 1994. Plant Proteins in Relations to Human Protein and AminoAcid Nutrition. American Journ. of Clinical Nutr. 59, p. 12035-12125.

Whitney, E. and Rolfes, S. R., 2008. Understanding Nutrition (11th ed.) California: Thompson Wadsworth. p. 154.

Kruger, M. C. and Horrobin, D. F., 1997. Andrew's Diseases of the Skin. Clinicals Dermatology (10th ed.) Saunders.

Uauy, R., Calderon, F and Mena, P., 2001. Essential Fatty Acids In Somatic Growth and Brain Development, World Rev. Nutr. Diet 89, p. 134-160.

Callaway, J., Schwab, U., Harvima, I., Halonen, P., Nykkanen, O. Hyvonen, P. and Jarvinen, T., 2005. Efficacy of Dietary Hepseed Oil in Patients with Atropic Dermatitis, J. Dermatolog. Treat 16(2), p. 87-94. 
Reiltel, J. A. and McDonald, A., 2006. Antiarrhythmic Effect of Omega 3 Fatty Acid. The American Jour. of Cardiology 98(4A), p. 50-60.

Cunnane, S. C., 2003. Problems with Essential Fatty Acids: Time for a New Paradigm? Progress in Lipid Research 42(6), p. 544-568.

Ruiz-Gutlerrez, V. Muriana, F. J., Guireero, A., Cert, A. M., Villar, J., 1996. Plasma Lipids, Erythrocyte Membrane Lipids and Blood Pressure of Hypertensive Women after Ingestion of Dietary Oleic Acid from Two Different Sources. J. Hypertens 14, p. 1483-1490.

Haug, A. Hostmark, A. T. and Harstad, O. M., 2007. Bovine Milk in Human Nutrition: A Review. Lipids in Health and Disease 6, p. 25.

Vassilious, E. K. Gorizalez, A. Garcia, C. Tadros, J. H. Ghakraborty, G. and Toney, J. H., 2009. Oleic Acid and Peanut Oil High in Oleic Acid Reverse the Inability Effect of Insulin Production of the Inflammatory Cytokine TNF and both In vitro and In vivo Systems. Lipids in Health and Disease 8, p. 25.

de Silva, P. S., Lusen, R. Shrestha, S. S., Khawu, K. T., Hart, A. R., 2014. Dietary Arachidonic and Oleic Acid Intake in Ulcerative Colitis Etiology: A Prospective Cohort Study using 7-day Food Diaries. Eur. J. Gastroenterol Hepatol 26, p. 11-18.

Rivers, J. P. Sinclain, A. J., Craqford, M. A., 1975. Inability of the Cat to Desaturate Essential Fatty Acids. Nature 258(5531), p. 171-173. 